\title{
Historical Archaeology in the Iberian Peninsula
}

Tânia Manuel Casimiro

IHC/IAP NOVA University of Lisbon

Lisbon, Portugal

tmcasimiro@fcsh.unl.pt

\section{Introduction}

What is the intention behind talking about Portuguese and Spanish historical archaeology coextensively? Were these countries identical to such an extent that their archaeology should be jointly interpreted? Or are their respective ontological perspectives and disciplinary concerns so distinct that two different papers should be written? When taking into account the developments in historical archaeology over the last 30 years, both countries have faced similar challenges and disciplinary trajectories. Their geographical, political and cultural proximity created comparable conditions and experiences during the Early Modern period, making a joint approach the most sensible. For example, their politics and economies during this period were intertwined in various ways: several marriages took place between their respective noble families; proximal ports traded constantly with each other; and even one king ruled both territories for 60 years (1580-1640). In addition, there is considerable evidence of people travelling between the two countries and settling in either during the Early Modern period (Fig. 1). This closeness (which may also be traced back to previous periods) should not be ignored in the context of historical archaeology, as both countries share the same thematic basis in the field (Azkarate \& Escribano-Ruiz 2014: 88). If a combined perspective seems superfluous when talking about local contexts, it is integral when a more general or international approach is undertaken.

\section{Defining Historical/Early Modern Archaeology}

The general designation of 'historical archaeology' in countries such as the United States, Australia or Brazil, among others, is usually associated with archaeological material and deposits from the late fifteenth century (European arrival in the Americas) to the nineteenth or even the twentieth century, a timeframe generally accepted in publications and congresses of historical archaeology (Deetz 1977: 5; Montón Subias \& Abejez 2015: 14; Mehler in press). In Portugal and Spain, the designation of historical archaeology is seldom used, the most widespread terms being Arqueologia Moderna or Arqueologia PósMedieval, since historical archaeology has a broader sense if understood as the archaeology of a time containing written records (Montón Subias \& Anejez 2015: 13). 
In Spain, historical archaeology begins in 1492, the iconic date marking the end of the Middle Ages in the conquest of the Muslim Emirate of Granada and Columbus' arrival in the Antilles. In Portugal, the defining date marking the division between medieval and Early Modern periods is more complicated, since it is assumed that the Discoveries (beginning with the conquest of Ceuta in 1415) represent a major turning point. A recent exhibition about this event clearly presented Portugal as no longer a medieval country (Teixeira et al. 2015a). However, no visible changes are perceptible in the archaeological record prior to the late fifteenth century (Gomes 2012). In this sense, both countries assume Arqueologia Moderna to have started around the same time.

If we take the late fifteenth/early sixteenth century to be the starting point for the Early Modern period, the end is more easily defined. In Portugal, the iconic date of 1 November 1755, when almost the entire country was affected by a major earthquake, conventionally marks the end of the Early Modern period. Although no one assumes that late eighteenth century is associated with the contemporary period, archaeological studies of the Early Modern period tend to stop around this time (Gomes 2012). In central and southern Portugal, the earthquake debris is frequently found in the archaeological record, and in archaeological practice it seems that only things from below this layer are considered worth preserving or excavating properly. In Spain, though no specific date is noted by scholars, the end of the Early Modern period is more debatable. In some areas of the country, nineteenth and twentieth century contexts are constantly overlooked by archaeological investigation, with the French Revolution (1789) often used as the cut-off point. However, in other areas, contemporary archaeology is almost assumed to be a branch of historical archaeology (Escribano-Ruiz 2017: 517).

Recently, contemporary archaeology, which some scholars consider to be archaeology of the twentieth century, has developed into a research field in Spain through studies of the Civil War. In Portugal also, projects are currently being developed in relation to twentieth century material culture (González-Ruibal 2010; Casimiro \& Sequeira 2019). In Spain, twentieth century archaeological contexts are excavated and recorded even in commercial archaeology, at least in urban centres (Escribano-Ruiz 2017: 516); while in Portugal, twentieth century context and artefact recovery is still rare, and when done so, rarely studied. However, if some countries categorise contemporary archaeology as part of a broader historical archaeology - a subject currently being debated in Spain (Meheler in press) -, in Portugal the theoretical framework in which nineteenth and twentieth century archaeology is developing differs completely from that of the Early Modern period (i.e. sixteenth-eighteenth centuries).

An exception to the general lack of interest in nineteenth century archaeology in both countries has been industrial archaeology, which has assumed a leading role in archaeological studies of the period. This has led some authors in Portugal as well as Spain to suggest that all archaeology dating to nineteenth century 
contexts is intrinsically industrial and that the labels of historical or contemporary archaeology cannot be assigned to these contexts and materials (Cerdà 2008: 72; Custódio 2015: 93).

Aside from this debate, it is generally agreed that historical archaeology in the Iberian Peninsula corresponds to the period between mid to late fifteenth/early sixteenth century till the late nineteenth century. Accordingly, this will be the chronological focus of this paper.

In both countries, historical archaeology findings are protected by archaeological and heritage laws, since protection is generalized to all archaeological finds regardless of their chronology (Portuguese Law 107/2001, 8 September and Spanish Law 16/1985, 25 July). While in Portugal this law is applied to the entire country, in Spain, due to its administrative division, specific regional laws affect the treatment of archaeological material accordingly.

Underwater archaeology is intentionally omitted from this discussion, even though the global navigation undertaken by Portugal and Spain in the Early Modern period left unquestionable influence on their organization and economy, and resulted in the development of important port cities. However, this is in fact an important aspect of Iberian historical archaeology and where archaeologists from the two countries can work together, especially since Early Modern shipbuilding is assumed to be a shared Iberian tradition (Alves 2001) by underwater archaeologists. The number of joint projects and archaeological evidence in this area are too extensive to be mentioned here, although a few have shared links in both countries, such as the Forest Resources for Iberian Empires: Ecology and Globalization in the Age of Discovery project, and several conferences in which researchers of both countries have presented joint work.

\section{Key Issues, Current Debates, Future Directions and Examples}

A few attempts to draw a general overview of historical archaeology in Portugal and in Spain have been written, and they present important information about the discipline, especially in terms of site and artefact catalogues (Represa 1996; Amores 1997; Gomes 2012; Gomes \& Casimiro 2013a; MontónSubias \& Abejez 2015; Escribano-Ruiz 2017). This paper is, nevertheless, the first to attempt a combined debate that will hopefully promote reflection not about the differences in Portuguese and Spanish Early Modern archaeology, which have been often enumerated, but the similarities. A list of every site where Early Modern archaeological finds have been found is not an objective of this paper, since this would entail describing hundreds if not thousands of sites in both countries. This also applies to the study and publication of the archaeological materials. This will only be referred to when contributing to an international overview of historical archaeology in both countries and how it can contribute to Iberian archaeology holistically. 
Development in the interest of Early Modern archaeology in Portugal and Spain can be traced back to the 1980s, although it took a few decades for it to be recognized as a discipline (Amores 1997; Gomes 2012). This was generally brought about by the increase in excavation and recording of urban contexts. Cities such as Lisbon, Silves, Coimbra, Porto (Portugal); and Seville, Madrid, Toledo and Barcelona (Spain), among many others, were central to this development. From the 1980s onwards, the number of publications has also multiplied. While "Spanish research on the post-medieval period is more widely disseminated on a global scale than one a local one" (Escribano-Ruiz 2017: 517), the same cannot be said about Portuguese research, which is still oriented more towards a national audience. In spite of the frequent participation of Portuguese archaeologists in international conferences, the publication of papers in English language journals seldom occurs. Indeed, both countries have come short in making their work widely available. Even if published in Portuguese or Spanish, most papers about sixteenth-eighteenth century archaeology are difficult to access (even when there are no publisher access limits), and only a small number of researchers make their papers available on online platforms.

At this point, it is necessary to talk about three different realities responsible for the development of historical archaeology in both countries. First of all, the necessity of recording and keeping all archaeological material (due to the Valletta Convention) made archaeological companies the primary custodians of it, though most archaeologists are not trained as historical archaeology experts. This has resulted in an enormous number of records and archaeological stores filled with unstudied artefacts. Save for a few exceptions, the majority of these sites were never investigated or properly published. Secondly, there has been a turn in research at some universities where $\mathrm{PhD}$ students have started to dedicate their theses to material and theoretical debates focusing on Early Modern archaeology. The third reality is related to archaeologists working for municipalities or museums who have conducted excavations of this period. Except for a few isolated cases, universities, municipalities and archaeological companies rarely work together in research projects. More frequently, archaeology students conduct some of their academic work using material excavated by archaeological companies or museums which is eventually published in journals or conference proceedings.

As for Early Modern research topics, they are quite similar in both Portugal and Spain. There is a strong interest in studying major buildings - primarily convents, fortresses and castles (some being medieval in origin but still active in the following centuries); military archaeology; or material culture studies (i.e. ceramics, see discussion below) (Figs 2 and 3). While ceramic studies were initially grounded culturehistorical approaches in the 1980s, following more recent contact with post-processualist archaeology, scholars have made use of new theoretical methods and subjects such as identity, inequality, gender, among other themes evolving from the initial empirical observations (Casimiro et al. 2019a; EscribanoRuiz 2019). Consequently, Iberian archaeologists are currently more interested in "developing thematic 
archaeologies which are not fragmented by time restrictions analysing societies in their socio-economiccultural changes overtime" (Azkarate \& Escribano 2014: 220).

Material culture in general and ceramic studies in particular are among the most widespread areas of study in historical archaeology, owing to the abundance of material but also due to the fact that Iberian ceramics were exported in large quantities, not only to the former Iberian colonies from the Atlantic to the Pacific, but to trade partners, especially in northern Europe, making them an important vector for understanding globalisation (Barrachina \& Escribano Ruiz 2012; Casimiro 2018). While international scholars have studied ceramics in former Spanish and Portuguese settlements in the New World for some time (Deagan 1987; Albuquerque 2008), it would take a few decades for Iberian archaeologists to recognize their importance and develop general studies which reflect their worldwide expansion (Gomes \& Casimiro 2013b; Buxeda i Garrigós et al. 2015; Casimiro \& Newstead 2019). In this field, archaeometry has played an important role since a large portion of research projects undertook provenance studies in order to understand what was being made in the Iberian Peninsula and later exported around the world. Five key research projects have dealt with this material. In Spain, the Tecnolonial, ArchSymb and CERANOR projects sought to understand the technological changes of Spanish and indigenous ceramics and the transmission of technical knowledge from coloniser to colonised populations, especially for tin glazed wares (Buxeda i Garrigós et al. 2015). As for Portugal, the two main projects investigating the international distribution of ceramics have been Portuguese Faience in the World (16 $6^{\text {th }}-18^{\text {th }}$ centuries) (Gomes \& Casimiro 2013a) and Portuguese Red Wares in the North Atlantic Trade (Casimiro and Newstead 2019). While the projects developed in Spain had a major focus on production and impact in colonial territories, Portuguese projects focused on production distinction (also involving archaeometric studies) although with a more international perspective, examining distribution both in colonial territories and between trade partners.

In spite of the ceramic distribution research foci in both countries, Spanish ceramics were the first to be recognized internationally through study and publication in countries such as the United States especially in Florida (Lister \& Lister 1974) -, UK and Ireland (Gerrard et al. 1995); while study of Portuguese ceramics outside the country has only recently begun to gain ground. In fact, most Portuguese ceramics, especially faience, have been mistaken for Spanish, Italian or Dutch varieties when encountered archaeologically in other countries. The reason behind this is not only the lack of knowledge about Portuguese ceramics - for papers about ceramics were only published in Portuguese - but the fact that both Portugal and Spain were producing similar wares (Fig. 2) impossible to distinguish without archaeometric analysis. From white, plain, tin glazed bowls and plates to botijas (olive jars) used to transport commodities in ships, both countries used and exported very similar vessels (Fig. 3). 
Aside from ceramics, other disciplines have seen increased application in historical archaeology. In the last decade, bioarchaeological studies of cemeteries have traced a portrait of post-medieval populations in several parts of the Iberian Peninsula. The same can be said for zooarchaeological studies, which are attracting academic attention in both countries, though the theoretical framework continues to be a focus on the economic and alimentary importance of animals.

Although both countries were heavily involved in Atlantic and worldwide expansion, seen in the occupation of several territories, the discussion of colonial encounters is still very recent and not very proportional. In Spain, archaeology has engaged with this theme consistently, especially in the Canary Islands, where Spanish colonial occupation left quite a significant impact (Montón-Subias 2015; MontónSubias et al. 2016). In Portugal, few publications have dealt with this subject (Coelho 2018; Casimiro et al. 2019).

However, colonisation is one of the main research areas where we see Spanish and Portuguese archaeologists working together. At the Society for Historical Archaeology conference in Leicester in 2013, a session was organized by André Teixeira and Javier Iñanez with the title Territory, settlement and material culture in the Iberian colonial empires $\left(16^{\text {th }}-18^{\text {th }}\right.$ centuries). Just a year later, a group of young researchers - Joana Torres, Miguel Busto Zapico, Regis Barbosa and Sergio Escribano Ruiz - organized a session in the JIA Conference (Young Researchers in Archaeology) entitled Towards Archaeology of Colonization: Living in Between Continents in the Early Modern Period. In 2018, in the Barcelona European Archaeologists Association annual meeting, Javier Iñañez and André Teixeira once again organized a session named Archaeology of Material Culture and Territory within the Iberian colonial empires $\left(15^{\text {th }}-18^{\text {th }}\right.$ centuries). Despite the great interest and discussion generated in these respective sessions, there have been no published proceedings discussing similarities or differences in Iberian colonialist initiatives from an archaeological perspective. The colonial and postcolonial debates promoted by these conference sessions are still very much focused on material culture and less on the political, cultural and social implications of colonialism (then and now), or even decolonisation, a subject that is seeing debate in Spain (Montón-Subias et al. 2016).

In 2015, Paulo Funari and Maria Ximena Senatore edited a book entitled Archaeology of Culture Contact and Colonialism in Spanish and Portuguese America, which shows the disparate treatment of the topic by Spanish and Portuguese scholars. Of the book's seventeen chapters (not counting the introduction and conclusion), only four are dedicated to Portuguese colonialism, and Portuguese archaeologists only participated with one paper, focusing on the trade and exchange of objects, plants, animals and people (Teixeira et al. 2015).

Several research projects and workshops are currently being undertaken investigating Early Modern trade and colonialism. In October 2019, a one-day seminar organized by Teresa Canepa and the author will be 
held in London, entitled Chinese porcelain in the Iberian Peninsula, $16^{\text {th }}-18^{\text {th }}$ centuries: an archaeological perspective on trade and consumption, which intends to debate the similarities and differences between Spanish and Portuguese consumption of this global product. The European funded project entitled The construction of early modern global Cities and oceanic networks in the Atlantic: An approach via Ocean's Cultural Heritage (CONCHA) is currently developing research agendas with multiple partners in Portugal, Spain, Ireland, France, Cape Verde, São Tomé and Principe, Colombia, Brazil and the United States. One of its objectives is to understand "the rise of global capitalism in its early form ("colonial mercantilism"), by using coastal and underwater archaeological context analyses". Although a few workshops and conference sessions have been held, no publications have appeared yet, although this project will probably set a new benchmark for Iberian and Atlantic collaborations. No information on the project website mentions whether any attention will be given to the Atlantic cities in the Iberia Peninsula or solely in the colonised countries.

In terms of fieldwork, Spanish archaeologists have worked extensively in South America (e.g. Argentina and Chile) and even in the Basque fisheries of Newfoundland, while Portuguese archaeologists have conducted much research in Northern Africa (Ksar es-Seghir, Ceuta, El Jadida - Mazagan), where colonialism did not gain the ethical implications it has in southern African or Brazilian territories. Only recently have Portuguese archaeologists stared to work in countries such as Cape Verde, which has not allowed time for publication of results. It must be noted that archaeology in Portugal itself, and in Spain as well, has largely ignored the study of slavery, which has recently started to emerge (Casimiro et al. 2019b). A combined Iberian perspective on Atlantic colonialism would be a fruitful research avenue, especially one that takes into account how similar cultural backgrounds may have influenced the type of occupation undertaken, and how both countries reacted to the abolition of slavery and colonialism from an archaeological point of view. It would be interesting to extend this discussion beyond the eighteenth century and apply it to subjects such as the abolition of slavery in the Iberian empires, the loss of the African colonies in the twentieth century, and general processes of decolonisation. Archaeology can provide fundamental contributions to these discussions.

As can be seen, although numerous studies have been conducted in Iberia, historical archaeology is still largely confined to site reports and the study/curation of specific collections. Broader debates about major themes are still largely absent from archaeological publications and conferences in both countries. On the other hand, we should not ignore that both countries have in fact regional differences and, while in Portugal the focal point of research and fieldwork is Lisbon, in Spain, the Basque Country, Andalusia and Catalonia are the primary research areas for historical archaeology (Bengoetxea Rementeria, 2004; Barrachina \& Escribano-Ruiz 2012). PhD researchers in both countries tend to pursue more holistic/general approaches and remove the major focus from these areas. 
In terms of tertiary education, post-medieval archaeology, excluding industrial archaeology, is only taught in two universities in Portugal, and the number of academic university staff with the pertinent expertise is quite small. Although Sergio Escribano mentions that "it is not uncommon to find degree courses at Spanish universities which include post-medieval archaeology" (Escribano-Ruiz 2017: 516), a recent survey (Mehler in press) refers to only three such permanent positions in Spanish universities (Granada, Seville and the Basque Country), suggesting that the teaching of courses may be in the hands of nonpermanent staff. In Portugal, the number is higher - six between Lisbon, Coimbra and Porto. However, in both countries the number, especially in Spain, is low, also taking into account the number of universities that offer degrees in archaeology. Nevertheless, the number of PhD students and post-doctoral researchers working on post-medieval topics is increasing in both countries. While no formal survey has been made, research papers by post-medieval Iberian researchers have increased in the last two decades.

In terms of publication, there is no specific platform for publishing historical archaeology work in either country, and post-medieval papers appear frequently in general archaeology journals. In Portugal there is only about a dozen archaeological journals, and historical archaeology papers are published predominantly in Almadan and O Arqueólogo Português. In Spain, archaeological publication is much more widespread across some 70 journals (Armada 2017). Historical archaeology papers appear occasionally in journals such as Complutum, Archeogazte, Acta Historica et archaeological mediaevalia or Territorio y Arqueología.

\section{Conclusion}

Due to its history, the Iberian Peninsula is very much a multicultural world. The Muslim domination until late fifteenth century culturally connected a large portion of the population of this vast territory with people from northern Africa. By that time, the Atlantic expansion of both countries forced the entrance of populations from around the globe, although African slaves were the majority, they themselves came from diverse cultural backgrounds. There are numerous texts from the Early Modern period in which foreigners note surprise at the number of black Africans in Lisbon and Seville (Caldeira 2017). This mixed population made Spain and Portugal unique in the wider context of Europe.

Concerning material culture, the similarities between Portugal and Spain continued for an extended period, which may be seen, for example, in the similarity of sixteenth and seventeenth century tableware and transport jars. Whether there was a one-way influence or both countries were simply maintaining practices stemming from a common cultural background, which could go back to the Romans or the Islamic presence, is something worth investigating in the future.

Archaeological excavations, especially in urban areas, as well as research projects have greatly increased in the last two decades increasing the general knowledge about historical archaeology in both countries. 
Though most of these projects are geographically confined and relate to specific landscapes or cities, they have revealed the evolution of cities and buildings throughout the centuries, as well as how people lived in the past and their reactions to the globalisation occurring at the time. The significance of these projects lies in their revealing a past that until the 1990s was not even considered as archaeology, and although the general law protects the sites and material coming from them, they remained poorly studied until 10 years ago.

In sum, there has been no lack of research in Portugal or Spain in historical archaeology in recent years, with numerous papers published every year. The problem remains that most of this research continues to be produced for an internal audience and written in the national languages. Although urban areas and city consumption are well represented in research topics, several lacunae remain. For example, rural areas have seen far less work, making non-urban populations in the sixteenth-eighteenth centuries poorly understood. The same can be said about religious communities such as convents and monasteries, on which only a few papers have been published.

Considering the global importance of both countries in the last 500 years in cultural, political and economic spheres, there is a comparable lack of internationally oriented academic dissemination. Consequently, it is time for researchers in both countries join forces and develop joint research projects that could contribute to understanding the reasons for mutual similarities in their respective material culture traditions and colonial contacts in the Early Modern period, and engage with the international community.

\section{Cross-References}

Atlantic World: Historical Archaeology

Brazil: Historical Archaeology

Ceramics as Dating Tool in Historical Archaeology

European Contact and Global Expansion (Post-AD 1500): Historical Archaeology

Historical Archaeology

\section{References}

Albuquerque, P.T.S. 2008. A Faiança Portuguesa - demarcador cronológico na arqueologia brasileira, in Actas das 4as Jornadas de Cerâmica Medieval e Pós-Medieval. Métodos e resultados para o seu estudo: 221-270. Tondela: Câmara Municipal de Tondela.

Alves, F. (ed.). 2001. Proceedings. International Symposium on Archaeology of Medieval and Modern Ships of Iberian-Atlantic Tradition. Hull remains, manuscripts and ethnographic sources: a comparative approach. Lisbon: Centro Nacional de Arqueologia Náutica e Subaquática / Academia de Marinha. 
AMORES, F. 1997. La arqueología postmedieval en Espana. Panorama y perspectivas. Archeologia Postmedievale 1: 51-67.

ARMADA, X.L. 2017. Las revistas de arqueologia en España, in Andrés, C (coord.) El poder del pasado. 150 años de arqueología en España: 90-91. Madrid: Ministerio de Educación, Cultura y Deporte de España.

AzkARATE, A. \& S. Escribano. 2014. De la arqueología histórica a la arqueología del colonialismo, Una reflexión desde la experiencia europea: "Arqueología de los primeros asentamientos urbanos españoles en la América Central y Meridional, Actas del I seminario internacional RII_UC: 87-109. Madrid: Universidad Politécnica de Madrid.

BARRACHINA, C.P. \& S. ESCRIBANO-RUIZ. 2012. Las producciones cerámicas vascas de época moderna: Un caso práctico de arqueología histórica, in J. Cascalheira and C. Gonçalves (eds.) Actas das IV Jornadas de Jovens em Investigação Arqueológica, JIA 2011 1: 219-224. Faro: Universidade do Algarve.

BengoetexeA Rementeria, B. 2004. Arqueologia de la Edad Moderna: Valorixación y reflexiones en torno a una disciplina en construcción. El ejemplo de la C.A.V. Kobie 6(2): 667-682.

Buxeda i Garrigós, J., M. Madrid i Fernandez, \& J. IÑañez (eds.). 2015a. Global Pottery Proceedings - $1^{\text {st }}$ International Conference for Historical Archaeology e Archaeometry for Societies in Contact. BAR International Series 2761. Oxford: Hadrian Books.

Buxeda i Garrigós, J., M. Madrid i Fernandez, \& J. Iñañez \& F. Marcos Garcia. 2015 b. Archaeometry of the technological change in societies in contact. First examples for modern ceramics from the Crowns of Castille and Aragon in I. Buxeda, J. Garrigós, I. Madrid, M. Fernandez \& J. Iñañez (eds.) Global Pottery Proceedings $-1^{\text {st }}$ International Conference for Historical Archaeology $e$ Archaeometry for Societies in Contact: 3-26. BAR International Series 2761, Oxford: Hadrian Books.

DeETZ, J. 1977. In small things Forgotten: the archaeology of early American life, New York: Anchor Books.

CaldeIRA, A. 2017. Escravos em Portugal. Das origens ao século XIX, Lisbon: Esfera dos Livros.

CASIMIRO, T.M. 2018. A distribuição e consumo de louça de Lisboa na Europa do Norte (1600-1700), in J. C. Senna-Martínez, A. C. Martins, A. Caessa, A. Marques \& I. Cameira (eds.) Fragmentos de Arqueologia. Meios vias e trajectos: 160-168. Lisbon: Centro Arqueologia de Lisboa.

Casimiro, T.M., J.P. Henriques, V. Filipe \& D. Neves. 2019a. Pottery Use and Social Inequality in Mid18th century Lisbon. An Initial Approach, in K. Matejkova \& G. Blazkova (eds.) Europa PostMedievalis: 1-18. Oxford: Archaeopress. 
Casimiro, T.M., J.P. Henriques, V. FiliPe \& S. Simões. 2019b. Mobility and identities. The case of the so-called African pots. International Journal of Historical Archaeology. doi.10.1007/s10761-019-00504$\mathrm{Z}$

Casimiro, T.M. \& S. Newstead. 2019. Portuguese coarsewares in North Atlantic trade $\left(16^{\text {th }}-18^{\text {th }}\right.$ centuries). American Ceramic Circle Journal 20: 59-81.

Casimiro, T.M. \& J.L. Sequeira. 2019. Os deuses devem estar loucos... ou a emergência de uma Arqueologia Contemporânea em Portugal. Almadan Online 22(3): 88-97.

CERDÀ, M. 2008. Arqueología industrial. València: Universitat de València.

Coelho, R. 2018. Topographies of Freedom. Anthropology Now 10(1): 72-92.

CustóDiO, J. 2015. O Território e o Tempo da Arqueologia industrial. Intervenção e investigação: realidades de hoje, perspectivas de futuro. Almadan 18 II série: 80-95.

DeAgAn, K. 1987. Ceramics, Glassware, and Beads (Artifacts of the Spanish Colonies of Florida and the Caribbean, 1500-1800 - Volume 1). Washington: Smithsonian Institution Press.

ESCRIBANO-RUiZ, S. 2014. Cultura material y fuentes escritas en los estúdios arqueológicos de las pesquerías vascas de Canadá (siglos XVI al XVIII), una valoración crítica sobre su interacción. Munibe Antropologia-Arkeologia 65: 239-247.

Escribano-Ruiz, S. 2017. Recent Past Archaeology in Spain. Post-Medieval Archaeology 51(3): 516517.

ESCRIBANO-RUIZ, S. 2019. Olor a sangre. La pesca vasca del Atlántico Norte en época moderna interpelada desde una posición colonial y sensorial. Arqueología Iberoamericana 41: 52-61.

Funari, P. \& M. Ximena SenAtore (eds.). 2015. Archaeology of Culture Contact and Colonialism in Spanish and Portuguese America. New York: Springer.

Gerrard, C., A. Gutiérrez \& A. Vince (eds.). 1995. Spanish Medieval Ceramics in Spain and the British Isles. BAR International Series 610. Oxford: Hadrian Books.

Gomes, M.V. \& T.M. CASIMIRO (eds.). 2013a. On the world's routes. Portuguese Faience (16th-18th centuries). Lisbon: Instituto de Arqueologia e Paleociências.

Gomes, R.V. 2012. A Arqueologia da Idade Moderna em Portugal - contributos e problemáticas. $O$ Arqueólogo Português Série V(2): 13-75.

Gomes, R.V. \& T.M. CAsimiro. 2013b. Post-medieval archaeology in Portugal. Post Medieval Archaeology 47(1): 17-34.

GonzÁlez-Ruibal, A. 2010. Contra la pospolítica: arqueología de la Guerra Civil Española. Revista Chilena de Antropología 22(2): 9-32.

Leister, F. \& R. LeISTER. 1974. Maiolica in Colonial Spanish America. Journal of Historical Archaeology 8(1): 17-52. 
MeHLeR, N. In press. Historical Archaeology in Europe. in A. Zarankin, J. Symonds \& Ch. Orser (eds.) Handbook on Historical Archaeology. London: Routledge.

Montón-Subias, S. 2015. Colonialismo, Monarquía Hispánica y cultura material. Algunas contribuciones desde la Arqueología, Índice Histórico Español 128: 137-174.

Montón-Subias, S. \& L. Abejez. 2015. Qué es esa cosa llamada Arqueología Histórica? Complutum 25(1): 11-35.

Montón-Subias, S., M. Cruz Berrocal \& A. Ruiz Martínez. 2016. Archaeologies of Early Modern Spanish Colonialisms. New York: Springer.

RePresA, F. 1996. Post-Medieval Archaeology in Spain: An Overview. World Archaeology Bulletin 7: $137-148$.

TeiXeira, A., F. Paredes \& R. Silva (eds.). 2015a. Lisboa 1415 Ceuta. História de Duas Cidades. Lisbon: Câmara Municipal de Lisboa/Ciudad Autonoma de Ceuta.

Teixeira, A., J. Torres, \& J. Bettencourt. 2015b. The Atlantic Expansion and the Portuguese Material Culture in the Early Modern Age: An Archaeological Approach in P. Funari \& M. Senatore (eds.) Archaeology of Culture Contact and Colonialism in Spanish and Portuguese America: 19-38. Berlin: Springer.

\section{Further Reading}

[Please enter your further readings here and use Antiquity style ...(optional)]

\section{Figure Captions}

Fig. 1 - Map of the Iberian Peninsula with the places mentioned in the text.

Fig. 2 - El Born Market - Barcelona

Fig. 3 - Eighteenth century house - Lisbon

Fig. 2 - Tin glaze ware bowls. Spanish on the right and Portuguese the left.

Fig. 3 - Olive Jars. Portuguese product on the right and Spanish on the left. 
